\title{
HEALTH RISK IN ROAD TRANSPORT WORKERS PART I. OCCUPATIONAL EXPOSURE TO CHEMICALS, BIOMARKERS OF EFFECT
}

\section{JOLANTA GROMADZIŃSKA and WOJCIECH WĄSOWICZ}

Nofer Institute of Occupational Medicine, Łódź, Poland

Biological and Environmental Monitoring Department

\begin{abstract}
Motor vehicle emissions constitute a mixture of different chemicals: volatile organic solvents, polycyclic aromatic hydrocarbons, heavy metals, isocyanates, etc. Drivers working in car cabins are exposed to chemicals deriving from incomplete combustion of fuels, exhaust emissions from working engines and fuel evaporation. Concentrations of these substances are rather low and do not exceed the applicable hygiene standards, but some of them pose, or are suspected to pose, carcinogenic risk. The interaction of chemical substances with human cells and tissues can lead to a number of modifications of metabolic pathways at a cellular level. The first biological mechanism of metabolic modulation is an inflammatory state and oxidative stress generation. The aim of this review is to analyze biomarkers of effect and to assess the hazard of occupational exposure of drivers. Int J Occup Med Environ Health. 2019;32(3):267-80
\end{abstract}

Key words:

drivers, occupational exposure, markers of occupational exposure, inflammation, oxidative stress, chemicals

\section{INTRODUCTION}

Drivers constitute one of the occupational groups that are exposed to a number of physical and chemical agents, the health effects of which have not been comprehensively recognized yet. It is presumed that, in the case of this occupational group, the risk of some diseases being a consequence of the performed work, such as cardiovascular and musculoskeletal system diseases, gastrointestinal disorders, as well as some neoplasms, is increased [1]. It may be related to a high level of stress resulting from the necessity to ensure safety in intense traffic, time pressure, irregular working hours and meals, and a low physical activity during the hours of work $[2,3]$. Professional drivers, when working in the limited space of a car cabin, are exposed to a risk of adverse health effects caused by both physical and chemical agents. Changing conditions, sometimes extreme temperatures, noise, vibrations and the lack of fresh air, which prevail in a car cabin, have a negative influence on the health status. Out of all chemical agents, exposure to dusts, heavy metals, volatile organic compounds (VOCs), polycyclic aromatic hydrocarbons (PAHs), etc. becomes crucial in assessing the health status of this group of workers [4-6].

Road transport workers are exposed to air pollutants that are side effects of fuel combustion, e.g., Diesel engine exhaust occurring along transport routes, especially

Funding: this work was supported by the Polish Ministry of Health - the National Health Program for 2016-2020 (project No. 6/4/3.1h/NPZ/2016/312/1659/D entitled "Monitoting of physical, chemical and biological hazards in the workplace," project manager: Prof. Wojciech Wasowicz).

Received: March 28, 2018. Accepted: November 2, 2018.

Corresponding author: Jolanta Gromadzińska, Nofer Institute of Occupational Medicine, Biological and Environmental Monitoring Department, św. Teresy 8 , 91-348 Łódź, Poland (e-mail: jolanta.gromadzinska@imp.lodz.pl). 
in the urbanized areas where buses and other vehicles using combustion engines operate, and also in the air of bus depots or garages [7]. The main transport-related air pollutants include gaseous chemical pollutants (organic and inorganic), including nitrogen oxides $\left(\mathrm{NO}_{\mathrm{x}}\right)$ that are generated during the combustion of fuels in engines, sulfur oxides $\left(\mathrm{SO}_{\mathrm{x}}\right)$ with a predominance of sulfur dioxide $\left(\mathrm{SO}_{2}\right)$ that are generated during the combustion of diesel oil, and hydrocarbons associated with the operation of engines using liquefied petroleum gas as a fuel. The suspended particulate matter may contain toxic substances such as polycyclic aromatic hydrocarbons (e.g., benzo(a)pyrene, nitropyrene), heavy metals, dioxins and furans [6].

The presence of methanol, aromatic hydrocarbons being fuel components, i.e., benzene, ethylbenzene and aromatic hydrocarbons with 9 carbon atoms, as well as naphthalene and xylene, has been detected in the air sampled from car cabins [8]. Moreover, polycyclic aromatic hydrocarbons, being mainly derivatives of pyrene, anthracene, phenanthrene, and 4,4'-methylenebis (phenylisocyanate), have been identified.

The composition of Diesel engine exhaust depends on the components of the used diesel, the degree of engine wear, its under-heating, as well as engine work in the neutral gear [7]. The substances emitted by Diesel engines, apart from the substances mentioned, include aldehydes (formaldehyde and acetic aldehyde), ammonia, sulfur, nitrogen and carbon oxides, as well as nitro derivatives of hydrocarbons, lead, platinum and others. The listed compounds are often adsorbed on the particles of suspended dust [8]. The gases and chemicals adsorbed on dust particles have a negative influence on the human body, i.e., they have an irritating or sensitizing effect, they impair the circulatory, nervous and hormonal systems, and some of them are carcinogenic [9].

Studies performed in the Nofer Institute of Occupational Medicine, Łódź, Poland, have indicated that the concentrations of chemical substances identified in the working environment of drivers are low and do not exceed the applicable hygiene standards [7]. This confirms the effectiveness of the filters used in the examined cars. However, even a subliminal effect of low concentrations of chemical substances has an impact on the metabolic pathways that take place in the human body. In addition, among the identified substances there are some carcinogens whose effect on the body has no threshold. The chemicals present in the polluted air, after entering the body via inhalation and/or skin, whether directly or after biotransformation into reactive metabolites, may act with macromolecules of cells and result in the activation of inflammatory mediators (cytokines, heat shock proteins), as well as induce oxidative stress.

\section{METHODS}

For this review, the authors searched through articles published in January 2000 - September 2018 using the online database PubMed. The search was conducted using the following key words: occupational exposure drivers, taxidrivers, markers of exposure and effects of exposure, combined with such phrases as volatile organic compounds, heavy metals, polycyclic aromatic hydrocarbons, oxidative stress, DNA damage, telomere length and inflammation. Only publications in English were selected.

In total, 627 potentially relevant articles were found. The available publications mainly concerned the exposure of drivers to physical agents (vibrations, noise) or their unhealthy lifestyles (irregular meals, irregular sleep, stress associated with road traffic). When selecting the articles, special emphasis was placed on:

- exposure to chemical substances,

- biomarkers of exposure,

- potential health effects of exposure,

- characteristics of the study groups (size of the examined groups, age, gender, seniority in a certain profession, type of the performed work - a taxi driver, a bus driver in a big city, a driver on long distance routes). 
When selecting the articles for the analysis, particular attention was paid to the studies performed in European countries (24 papers), along with 8 papers written in USA, 12 in Asian countries, 4 in South America and 1 in Australia. In addition, the study included 4 papers available in the database of Nofer Institute of Occupational Medicine in Łódź and the Institute of Environmental Protection in Warsaw, published in Polish.

In the publication, all the analyzed markers of exposure and biomarkers of effects were compared between the exposed group and the reference group, or in the same group before and after the end of the work shift. In the article, only those data were used whose authors had indicated statistically significant differences between the examined group and the reference group, or before and after finishing work. Finally, the number of publications was reduced to 62 articles.

\section{RESULTS}

Epidemiological studies have provided strong evidence that the air pollution caused by vehicles is one of the most important problems in big agglomerations, especially in developing countries. On the one hand, emissions from vehicles contain heterogenic mixtures of chemicals, and it needs to be mentioned that people who stay inside car cabins and on the roadside are more exposed to carbon monoxide, aldehyde, hydrocarbons and some metals than those who stay outdoors $[10,11]$. On the other hand, the level of exposure to particulate matter or VOCs inside the cabin is comparable with that in the ambient environment [12].

Detailed studies on air quality in 51 cabins of private vehicles, which were carried out in the summer season of 2017 in Hong Kong, showed that the concentration of $\mathrm{CO}_{2}$ in $16 \%$ of the examined vehicles exceeded the permissible occupational exposure limits determined by the American Conference of Governmental Industrial Hygienists (ACGIH), and the Occupational Safety and
Health Administration (> 5000 ppm), whereas $96 \%$ exceeded the level of $1000 \mathrm{ppm}$, which is recommended by the Hong Kong Department of Environmental Protection for Indoor Air Quality in offices and public places. Therefore, the permissible VOCs concentrations were exceeded in $24 \%$ of the examined vehicles [12].

Inhalation is the main route via which air pollutants enter the human body. The consequences of exposure to such diversified chemical compounds include air pollutionrelated adverse respiratory effects, like airway inflammation, decreased lung function and the development of cardiovascular diseases. The pathogenic interaction mechanism of xenobiotics with human tissues and cells has not been fully explored; however, it is known for sure that these mechanisms include oxidative stress, qualitative and quantitative modifications of the cell receptors of target proteins, immunomodulation, and an inflammatory state inducement $[13,14]$.

\section{Volatile organic compounds}

Traffic is the major source of VOCs, but they are also emitted by numerous branches of industry. Commercial gasoline contains VOCs, including benzene, toluene, ethylbenzene and xylenes (BTEX) [15].

Benzene is classified by the International Agency for Research on Cancer as a substance belonging to Group 1 (carcinogenic to humans) and ethylbenzene to Group 2B (possibly carcinogenic to humans) [16]. Despite its content being decreased in fuels from 5\% to 1\% (PE 98/70/ EC Directive [17]), due to an increasing number of motor vehicles on the roads, exposure to benzene is still a major public health concern [9]. In Italy, before the Directive was published, in 2001 the environmental standard regulating benzene concentrations amounted to $10 \mu \mathrm{g} / \mathrm{m}^{3}$. The objective was to reduce it to $5 \mu \mathrm{g} / \mathrm{m}^{3}$ within 10 years' time. However, in the centers of large Italian cities, in the period of 2000-2001, high concentrations of benzene, amounting to $>20 \mu \mathrm{g} / \mathrm{m}^{3}$, still prevailed [18]. 
It is assumed that a whole lifetime exposure to benzene in a concentration of $1 \mu \mathrm{g} / \mathrm{m}^{3}$ poses a risk of leukemia with the incidence of 6 disease cases/million of residents [19]. A paper published in 2012 analyzed individual exposure to benzene among Italian non-smoking traffic policemen who worked in road traffic $(\mathrm{N}=62)$, police drivers $(\mathrm{N}=22)$ in a large Italian city, and road workers working in rural areas $(\mathrm{N}=57)$. It was observed that benzene concentrations in the air of the working environment of both groups of policemen amounted to $8.9 \pm 2.4 \mu \mathrm{g} / \mathrm{m}^{3}$ and $8.2 \pm 2.8 \mu \mathrm{g} / \mathrm{m}^{3}$, respectively, whereas among the road workers from rural areas all the obtained values were $<1.6 \mu \mathrm{g} / \mathrm{m}^{3}$ (below the limit of detection). In the case of the limit value of occupational exposure that equals $5 \mu \mathrm{g} / \mathrm{m}^{3}$, about $75 \%$ of the examined people were exposed to benzene concentrations exceeding the threshold limit value - the time-weighted average (TLV-TWA) values. Moreover, the obtained values of individual exposure of workers were significantly higher than the values obtained in stationary measurement points located in the same area [20].

Personal exposure to VOCs assessed in 2005-2006 among bus drivers working in the center of Prague (Czech Republic) did not show any differences between the summer and winter seasons, as compared with workers spending $>90 \%$ of their daily time indoors. The concentration of benzene was an exception, as it was significantly higher in the cabins of bus drivers during the winter season $\left(11.2 \pm 15.4 \mu \mathrm{g} / \mathrm{m}^{3}\right.$ vs. $\left.6.9 \pm 5.9 \mu \mathrm{g} / \mathrm{m}^{3}, \mathrm{p}<0.001\right)$ [21]. Studies have shown that benzene concentrations in car cabins are considerably higher than in the outdoor environment. This also concerns new generation cars with catalyzers. It is assumed that this elevated exposure in car cabins is associated with exhaust emissions from operating car engines as well as with fuel evaporation. Exposure to VOCs, and mainly to benzene, is influenced by ventilation and temperature inside a cabin, i.e., the heating and air-conditioning systems being turned on [22]. The size of expo- sure to benzene is influenced by a number of other factors, namely tobacco smoking and emissions from consumer products (paints, lacquers, adhesives, furniture), where in the case of smokers $90 \%$ of the exposure comes from tobacco smoke. Benzene emitted from traffic sources gets indoors and affects indoor air quality [19].

To assess the biological markers of benzene exposure, unmetabolized benzene excreted in the urine, or 2 of its metabolites, i.e., S-phenylmercapturic acid (S-PMA) or trans,trans-muconic acid (t,t-MA), were determined [23]. The above-mentioned biomarkers correlated significantly with benzene levels in the air. The biological exposure indices (BEI) of both these metabolites, determined by the Association Advancing Occupational and Environmental Health, are as follows: $500 \mu \mathrm{g} / \mathrm{g}$ of creatinine for $t, t-\mathrm{MA}$, and $25 \mu \mathrm{g} / \mathrm{g}$ of creatinine for S-PMA. Both these metabolites are used as indices of exposure to benzene, even though in the case of benzene concentrations within $3-12 \mu \mathrm{g} / \mathrm{m}^{3}$, which were determined in car cabins, no relationships between the concentration of benzene and the concentrations of the above-mentioned metabolites have been observed [9].

An increased concentration of excreted $t, t$-MA is influenced by sorbic acid and its salts, which are used as preservatives in many food preparations, and which are metabolized to $t, t$-MA [24]. The concentration of this metabolite in the urine of taxi drivers did not differ statistically when examined before and after the work shift; however, there was a tendency of $t, t$-MA to increase after the end of the work shift. The concentration of the excreted S-PMA depended on the concentration of cotinine in the urine $(r=0.673, p<0.002)$. Moreover, in Italian taxi drivers who were smokers, the S-PMA concentration was statistically higher after the end of the work shift than at the beginning of it [18]. In $36.4 \%$ of non-smoking policemen working in road traffic and police drivers, the urine S-PMA concentration was lower than the limit of detection [20]. 


\section{Polycyclic aromatic hydrocarbons}

Polycyclic aromatic hydrocarbons mainly come from anthropogenic sources and are identified both in various environmental matrices and in food. They are side products of numerous chemical processes. It is believed that each process associated with strong heating or incomplete combustion of organic matter may be a source of PAHs emission [25]. Tobacco smoke is yet another separate source of exposure to PAHs.

Due to their toxicity to humans, the following $17 \mathrm{com}$ pounds are most frequently determined: acenaphthene, acenaphthylene, anthracene, benzo(a)anthracene, benzo(a)pyrene, benzo(e)pyrene, benzo(b)fluoranthene, benzo(j)fluoranthene, benzo(k)fluoranthene, benzo(g,h,i)perylene, chrysene, dibenzo(a,h)anthracene, fluoranthene, fluorene, phenanthrene, pyrene and indeno(1,2,3-cd)pyrene. These compounds do not occur individually, but always as a mixture.

The best examined hydrocarbon belonging to the group of PAHs is benzo(a)pyrene (B(a)P) which, due to its strong carcinogenic effect and common occurrence in the environment, has been regarded as a marker for the whole group of PAHs. According to the International Agency for Research on Cancer (IARC), B(a)P is classified to Group 1 carcinogenic to humans [26]. Moreover, the products containing $\mathrm{B}(\mathrm{a}) \mathrm{P}$ and other PAHs (tobacco smoke, indoor emissions from household combustion of coal, diesel exhaust fumes, outdoor air pollution, and particulate matter) are also classified to Group 1 [27]. Numerous animal studies have confirmed carcinogenic properties of B(a)P. Exposure to B(a)P and/or its mixtures causes immunotoxic and teratogenic effects, and induces apoptosis and cell proliferation, as well as increased DNA methylation and DNA-PAH adducts formation.

The carcinogenic effect of other compounds is calculated in comparison to B(a)P. Personal monitoring of bus drivers $(\mathrm{N}=50)$ in Czech Republic on 2 consecutive days showed statistically significant lower B(a)P and car- cinogenic PAH concentrations in the vehicle cabins (for (B(a)P: $1.3 \pm 0.7 \mathrm{ng} / \mathrm{m}^{3}$ vs. $1.8 \pm 1 \mathrm{ng} / \mathrm{m}^{3}, \mathrm{p}<0.01$; for carcinogenic PAH: $7.1 \pm 3.7 \mathrm{ng} / \mathrm{m}^{3}$ vs. $9.4 \pm 5.5 \mathrm{ng} / \mathrm{m}^{3}, \mathrm{p}<0.05$ ) than in the ambient air [28]. Polycyclic aromatic hydrocarbons exposure can be assessed by means of the concentration of 1-hydroxypyrene excreted in the urine. As shown in 2 groups of Danish non-smoking workers exposed to air pollution, i.e., bus drivers $(\mathrm{N}=60)$ and mail carriers $(\mathrm{N}=88)$, the former excreted more 1-hydroxypyrene than the latter [29]. However, it needs to be underlined that the degree of toxic metabolites excreted from the body is not a direct and simple reflection of the size of exposure. It depends on age, gender, physical activity as well as the polymorphism of genes incorporated into the xenobiotics detoxification process, and their metabolites [29].

Diesel engine exhaust, apart from containing PAHs, is also a source of their nitro-derivatives, the most important representatives of which include 1-nitropyrene and 3-nitrobenzanthrone [30]. In 2012, 1-nitropyrene was classified by IARC as a probable human carcinogen (Group 2A). The major human urinary metabolites used as biomarkers of Diesel exhaust exposure include 6-hydroxy-1-nitropyrene and 8-hydroxy-1-nitropyrene [30]. The analysis of urine samples of Peruvian traffic workers $(\mathrm{N}=17$; minivan drivers, minibus drivers and motorcycle police officers), occupationally exposed to the Diesel engines exhaust, has demonstrated higher 1-nitropyrene metabolites than in the control group.

The sum of hydroxy-1-nitropyrene in the urine of exposed workers was $5.1 \pm 2.7 \mathrm{pg} / \mathrm{mg}$ creatinine, as compared with $1.6 \pm 3 \mathrm{pg} / \mathrm{mg}$ creatinine [30]. Exposure to tobacco smoke, especially among active smokers, has increased, to a statistically significant extent, the excretion of PAHs metabolites in taxi drivers as well as in employees exposed to Diesel engine exhaust [31]. The genotoxic and carcinogenic effect of PAHs metabolites, by creating adducts with DNA or generating oxidative stress. as well as proinflammatory processes during their biotransformation, has been documented [13]. 


\section{Heavy metals}

Road transport is one of the most significant sources of heavy metal emissions. In Poland, the emission of 8 metals is monitored, i.e., $\mathrm{Pb}, \mathrm{Cd}, \mathrm{As}, \mathrm{Cr}, \mathrm{Cu}, \mathrm{Zn}, \mathrm{Ni}$ and $\mathrm{Hg}$, where the emission of $\mathrm{Pb}, \mathrm{Cr}, \mathrm{Zn}, \mathrm{Ni}$ and $\mathrm{Cu}$ is related to road traffic. The emission of these metals is related to the combustion of fuel (e.g., the emission of lead despite using unleaded petrol), but also to the use of vehicle elements $(\mathrm{Cu})$, the wearing down of car tyres $(\mathrm{Zn})$ and the attrition of road surface [32]. The emission of lead to the environment, associated with road traffic, was 14 tons in 2014 (2.6\% of the total $\mathrm{Pb}$ emission), whereas the emission of cadmium was about 0.4 ton (i.e., $2.8 \%$ of the total emission) [33]. Chromium and $\mathrm{Ni}$ are released into the environment along with the exhaust from Diesel engines, as well as with products of friction breaking systems, and as a result of the road surface's wearing out [32].

The environmental and occupational exposure to lead and cadmium may be related to the development of hypertension, while lead has an additional documented neurotoxic and damaging kidneys effect $[34,35]$. Lead has been classified by IARC as an agent with a proved carcinogenic effect in animals, and as potentially carcinogenic to humans (Group 2A), whereas cadmium has been included in Group 1, i.e., among substances that are carcinogenic to humans. It is currently believed that the biological limit values (BLVs) should constitute the basis for assessing the exposure to lead and cadmium. Lead concentrations in blood, resulting from occupational exposure via the respiratory tract, should not exceed $500 \mu \mathrm{g} / \mathrm{l}$ in men and $300 \mu \mathrm{g} / \mathrm{l}$ in women of childbearing age ( $<45$ years), and the upper limit for cadmium is $5 \mu \mathrm{g} / \mathrm{l}$ [35].

Authors of the latest studies published in 2017 suggest that the BLVs for lead should be reduced to $100 \mu \mathrm{g} / \mathrm{l}$, due to its neurotoxic effect [36]. In the study of a population that was occupationally exposed to lead and cadmium, a statistically significant relationship between the concentrations of the above-mentioned metals in blood, and the systolic and dia- stolic blood pressure, was observed [34]. Tobacco smoking is another factor that increases exposure to heavy metals. Heavy metal exposure among professional drivers in both European countries and USA is controlled by the applicable regulations determining the reference values. Maintaining the occupational exposure limit is a significant issue in developing countries. The lead level in Jordanian automobile workers (automobile electronic engineers, exhaust workers, car mechanics, car metal workers, total $\mathrm{N}=60$ ) ranged from $15 \pm 1.6 \mu \mathrm{g} / \mathrm{dl}$ to $21 \pm 1.6 \mu \mathrm{g} / \mathrm{dl}$ in various automobile job categories, as compared with $4.3 \pm 0.5 \mu \mathrm{g} / \mathrm{dl}$ in the control group [37].

\section{Biological effects of chemical exposure in professional drivers}

Ambient air pollution affects the human population. The occupational or environmental exposure to polluted air is associated with an increased risk of many diseases - cancer, cardiovascular diseases, etc. Vehicles emit heterogeneous mixtures of particles and chemicals, mediating their negative health effects by the activation of biological processes, including the activation of inflammatory pathways and/or oxidative stress generation, and the acceleration of DNA damage, e.g., telomere shortening [38,39].

\section{Inflammatory state}

The stimulation of proinflammatory agents by particles of dust with adsorbed xenobiotics that get into the human body activates vascular endothelial cells and increases the expression of adhesion proteins that are responsible for the migration and adhesion of leukocytes to the vascular endothelium. Experimental data have indicated that exposure to environmental dust increases the percentage of cells that produce intracellular adhesion molecule-1 (ICAM-1) [40]. Interleukin 6 (IL-6) is one of the most universal markers of an inflammatory state. It is one of the most important cytokines, with the most multidirectional effect. It is a low molecular weight protein that is secreted mainly by cells of 
the immune system (monocytes, macrophages), regulating various biological processes, such as proliferation, differentiation, cell chemotaxis or synthesis of other proteins. On the one hand, IL-6 strongly stimulates inflammatory processes, including $\mathrm{B}$ lymphocytes differentiation. On the other hand, it stimulates the production of acute phase proteins, as well as participates in the feedback inhibition of tumor necrosis factor $\alpha(\mathrm{TNF} \alpha)$. Tumor necrosis factor $\alpha$ is a cytokine that takes part in almost all the phenomena that make up an inflammatory response (i.e., it initiates the synthesis of chemokines, enhances the expression of adhesion molecules, stimulates the liver to produce acute phase proteins, including C-reactive protein [CRP], and stimulates neutrophil phagocytosis and the cytotoxicity of macrophages, monocytes and eosinophils). Two independent studies conducted in a group of taxi drivers have detected a statistically significant increase in the concentration of proinflammatory processes mediators (IL-1 $\beta$, IL-6, $\mathrm{TNF} \alpha$, interpherone $\gamma, \mathrm{CRP}$ ) and a reduced concentration of anti-inflammatory IL-10, compared to the reference group [22,41]. Additionally, statistically significant linear relationships have been observed between the levels of proinflammatory agents in the plasma (IL-1, IL-6 and TNF $\alpha$ ) and the concentration of excreted 1-hydroxypyrene [31].

\section{Oxidative stress}

Oxidative stress is one of the critical processes being part of the pathogenesis of numerous pathological states in humans [40,42]. Oxidative stress is associated with the impairment of normal cellular metabolism, whereby the processes of reactive oxygen species (ROS) generation dominate over the processes of their elimination. Reactive oxygen species are generated during the normal metabolic processes occurring within human cells. At moderate concentrations, they form part of a proper cellular metabolism, regulating intracellular signal transduction pathways [43,44]. Oxidative stress is generated when, as a result of metabolic dysregulation, the oxidation of lipids, proteins and DNA, and/or oxidative damage of cells or tissues, take place [44]. This may lead to several disorders in the normal body functioning.

Oxidative stress may be induced by numerous factors, including exposure to chemical agents (the occupational and environmental exposure to chemical compounds, tobacco smoke, pharmaceuticals or polluted food), bacterial and viral infections, and too low antioxidants defenses [42]. Numerous studies have proven that exposure to particulate matter and chemical substances adsorbed to it leads to the granulocyte respiratory burst, an inflammatory state inducement associated with it and oxidative stress generation $[13,45]$. Oxidative stress may be an outcome of a direct interaction of xenobiotics with cell macromolecules. It may also result from xenobiotic biotransformation processes and the formation of ROS or intermediates with a reactive oxygen species structure [46].

Under a physiological condition, there is a balance between ROS generation and antioxidant defenses. Antioxidants are classified into 2 groups, depending on their function, i.e., preventive antioxidants and scavenging antioxidants, or chain breaking antioxidants. The first group of antioxidants includes antioxidative enzymes and trace elements connected with them, such as superoxide dismutase, glutathione peroxidase, catalase, glutathione reductase, DNA repair enzymes and albumin as sequestrators of metal ions. The second group consists of reduced glutathione, uric acid, antioxidant vitamins (A, C, E) and their precursors (e.g., carotenoids), as well as bioactive plant products (flavonoids) [47]. An improper diet, with an insufficient amount of antioxidants, as well as absorption disorders or some pathological states, may impair antioxidant defense.

Exposure to reactive oxygen species, when there is an insufficient antioxidant defense, may lead to oxidative damage in all macromolecules that are present in human cells. A direct measurement of oxidative stress biomarkers in in vivo studies is impossible due to short-lived ROS molecules. An alternative approach is to measure the prod- 
ucts of the reaction between ROS and cell molecules: proteins, lipids and nucleic acid, and/or antioxidant defenses, i.e., small molecular weight antioxidants individually (glutathione, uric acid, vitamins A, C, E) or as a pool of low molecular weight antioxidants, as the total antioxidant status, antioxidative enzymes (superoxide dismutase and glutathione peroxidase) and trace elements connected with them ( $\mathrm{Se}, \mathrm{Cu}, \mathrm{Zn}$ ), damaged DNA molecules, etc. [48].

The genotoxic and carcinogenic effect of PAHs metabolites via the formation of adducts with DNA or oxidative stress generation at the stage of quinones formation during biotransformation has been documented [21,49]. Also, volatile organic compounds, including benzene, may induce oxidative stress [50].

Malonyldialdehyde (MDA) is the main product of the peroxidation of polyunsaturated fatty acids and a consequence of damage to cell membranes [51]. Proteins also constitute target molecules for ROS, the consequence of which is damage to their secondary, tertiary and quaternary structure. Moreover, ROS may modify the active groups of aminoacids that make up proteins, and they may lead to the disintegration or aggregation of polypeptide chains [45]. An increase in MDA concentrations and protein carbonyl groups, as a marker of damage to lipids and proteins, has been observed in the plasma of taxi drivers, bus drivers and technical services workers, exposed to polluted air [31,52]. Rosner et al. [45] have examined the concentration of $15-\mathrm{F}_{2 \mathrm{t}}$-isoprostane $\left(15-\mathrm{F}_{2 \mathrm{t}}\right.$-iso $\left.\mathrm{P}\right)$ - a marker of peroxidation of arachidonic acid - in the urine of bus drivers. They have shown that $15-\mathrm{F}_{2 \mathrm{t}}$-isoP concentrations are higher in winter and spring, when the environmental and occupational exposure to PAHs is also higher [45].

Antioxidant enzymes, which are present in all cells and extracellular fluids, play a significant role in the defense of cellular structures against oxidative stress. Catalase and glutathione peroxidase (GSH-Px) break down hydrogen peroxide, GSH-Px - additionally organic peroxides. A statistically significant lower activity of these enzymes has been shown in the blood of taxi drivers when compared to the control group [31]. When analyzing the environmental exposure to PAHs, Delfino et al. have described a negative linear correlation between the activity of the following enzymes: catalase, GSH-Px and glutathione S-transferase in erythrocytes, and the concentration of 1-hydroxypyren in the urine, concluding that exposure to polluted air lowers antioxidant activity of the body [53]. The concentration of vitamin $\mathrm{C}-\mathrm{a}$ water soluble antioxidative vitamin - was significantly lower in the serum of taxi drivers when compared to the individuals who were not occupationally exposed. Moreover, the authors have shown a negative linear correlation between the concentration of this vitamin and the concentration of protein carbonyl groups, oxidized LDL and HDL cholesterol fractions, suggesting that exogenous vitamin $\mathrm{C}$ is necessary to defend against oxidative damage to cellular structures [31,52].

\section{DNA damage and telomeres shortening}

Barth et al. [13] have been the first to observe that inflammatory processes generated by exposure to chemical substances emitted in road traffic are related to DNA damage in peripheral blood lymphocytes in taxi drivers. The deoxyribonucleic acid damage, assessed by the use of the comet assay (tail moment, percentage DNA in the tail) and the frequency of micronuclei presence, was significantly higher in taxi drivers, in comparison with the control group. Also Goethel et al. have shown a statistically significant ( $p<0.001)$ increase in DNA damage, assessed via the comet assay in a group of 34 taxi drivers, when compared to individuals who were not occupationally exposed [8]. In a group of bus drivers who during one work shift cover a distance of $>100 \mathrm{~km}$ and have worked in this position for $>1$ year, a significantly higher concentration of 8-oxo-2' -deoxyguanosine (8-oxo-dG) has been observed when compared to office employees $(9.5 \pm 6.1 \mu \mathrm{g} / \mathrm{g}$ of creatinine vs. $8.1 \pm 5.1 \mu \mathrm{g} / \mathrm{g}$ of creatinine). Moreover, it has been shown that the drivers working $>50 \mathrm{~h} /$ week 
excrete statistically more 8-oxo-dG $(9.6 \pm 5.7 \mu \mathrm{g} / \mathrm{g}$ of creatinine, $7.3 \pm 5.4 \mu \mathrm{g} / \mathrm{g}$ of creatinine).

Based on the multiparametric regression analysis, it has been revealed that 8-oxo-dG concentration is higher in smokers, in employees who drink high-energy beverages, and in drivers who display a high level of physical activity [54]. The concentration of 8-oxo-dG is one of the markers of oxidative stress and oxidative DNA damage that are proportional to the extent of exposure to chemical agents. The concentration of 8-oxo-dG excreted with urine constitutes a reflection of the functional efficiency of cellular DNA repair mechanisms (cellular excision repair mechanism). The efficiency of the DNA repair mechanisms, which consists in the removal of damaged bases or whole nucleotides, depends on the age, health status, lifestyle, diet, metabolic rate, etc., of the examined individuals [55].

The assessment of the effects of environmental exposure to respirable dust $\left(\mathrm{PM}_{2.5}\right)$ in heavy traffic along transport routes, conducted among 72 students aged 20-35, has shown that the concentration of dust and PAH molecules adsorbed on it is positively correlated with the amount of the excreted damaged guanine derivatives, i.e., 8-oxo-dG and N7-methylguanine (N7-MeG). It is worth to mention that $\mathrm{N} 7-\mathrm{MeG}$ seems to be a more sensitive marker of exposure to respirable dust than 8-oxo-dG, as the excretion of $\mathrm{N} 7-\mathrm{MeG}$ with urine is about 1000 higher than in the case of 8-oxo-dG [48]. The excretion of N7-MeG is a marker of DNA damage related to the methylation process [49]. Exposure to respirable dust activates a phagocytosis process, during which the creation of NO is intensified, and then with the participation of reactive nitrogen species (RNS) - peroxynitrite. This compound may react with secondary amines/amides, forming methyl nitro compounds, also with DNA bases [56].

The length of telomeres is associated with the size of exposure to xenobiotics, the age of examined individuals, as well as their health status. Telomeres are repetitive nucle- otide sequences (TTAGGG)n, located at the ends of chromosomes which, along with the accompanying proteins, are supposed to prevent chromosomal damage. Errors in the process of genetic material replication, associated with age, and also with exposure, inter alia, to chemical substances, cause that telomeres in mammalian cells (including humans) become shorter with each cell division. Thus, many researchers believe that the shortening of telomeres is associated with age and may be considered a biomarker of a cell aging, sometimes described as "the molecular clock." It has been demonstrated that exposure to xenobiotics that accelerate telomeres shortening is harmful to the human body. In cross-sectional studies, it has been shown, inter alia, that exposure to polycyclic aromatic hydrocarbons, N-nitrosamines, pesticides and cadmium results in the shortening of telomeres [39]. It is believed that telomeres shortening is also affected by a developing inflammatory state and oxidative stress generation. A specific sequence of repetitive guanine nucleotides and a low activity of the repair systems of single DNA strands, occurring at the ends of DNA in chromosomes, favors telomeres shortening [57].

When studying police officers that patrolled streets and had 8-h shifts in road traffic, it has been noted that they have shorter telomeres measured in the leucocytes of peripheral blood than the reference group $(\mathrm{p}<0.001)$. Additionally, age dependent telomeres shortening, both among the exposed police officers $(<30$ years vs. $>40$ years, $\mathrm{p}<0.01$ ) and in the control group (for the same age groups $p<0.001$ ), has been noted. It has also been shown that telomeres shortening in the exposed workers is statistically significant, depending on the individually assessed exposure to benzene $(\mathrm{p}<0.004)$ and toluene $(\mathrm{p}<0.008)$. Moreover, significant differences in the length of telomeres (adjusted to the age of the examined individuals), depending on the habit of cigarette smoking, have been observed. No statistically significant differences depending on the number of smoked cigarettes per day or the 
duration of smoking, both in the exposed group and in the reference group, have been observed [39]. Short-term exposure ( $<2$ days) to $\mathrm{PM}_{10}$ dust has been found to result in the lengthening of lymphocyte telomeres of the exposed individuals, whereas exposure for $>14$ days has resulted in telomeres shortening. In the same study, a statistically significant dependence between the length of telomeres and blood pressure has been found [58,59].

It is thought that telomeres shortening is an accepted marker of individual as well as cellular aging processes. In in vitro studies, it has been shown that telomeres shortening in vascular endothelial cells is associated with the expression of molecules responsible for the development of atherosclerotic plaques [60], and with an increase in genetic instability [61]. This indicates that telomeres shortening may be potentially related to an increased risk of the circulatory system diseases and neoplasms $[62,63]$.

\section{CONCLUSIONS}

Occupational exposure to chemicals, even when it is low and does not exceed occupational exposure limits, may result in adverse health effects in the exposed workers. Chemical substances identified in the place of work of drivers may have sensitizing, irritating and carcinogenic effects, as well as impair the proper functioning of the nervous system. Therefore, monitoring the concentrations of these compounds in the air during the working hours of drivers seems reasonable. It also seems reasonable to monitor them in the biological samples collected from the exposed employees.

Inflammation and oxidative stress generation, as well as their size and related damage to important cellular structures, are influenced by, inter alia, lifestyle, including physical activity, diet and exposure to tobacco smoke. A sedentary lifestyle, low physical activity as well as irregular meals may lead to overweight in this occupational group. These agents may additionally intensify oxidative stress generation or increase the risk of pathological states de- velopment. Ensuring the adequate amounts of the necessary trace elements, antioxidants or bioactive substances of plant origin in a diet, which may have influence on methylation/demethylation of DNA, may modulate gene expression, enzymes activity and the processes of intercellular communication, and in fact reduce damage to the cells caused directly by exposure to, or presence of, ROS. Hence, the analysis of a diet and nutritional status is also important.

\section{REFERENCES}

1. Lewne M, Nise G, Lind M-L, Gustavsson P. Exposure to particles and nitrogen dioxide among taxi, bus and lorry drivers. Int Arch Occup Environ Health. 2006;79(3):220-6, https:// doi.org/10.1007/s00420-005-0047-6.

2. Siedlecka J. [Selected work-related health problems in drivers of public transport vehicles]. Med Pr. 2006;51(6):47-52. Polish.

3. Naug HL, Colson NJ, Kundur A, Kumar AS, Tucakovic L, Roberts $\mathrm{M}$, et al. Occupational health and metabolic risk factors: A pilot intervention for transport workers. Int J Occup Med Environ Health. 2016;29(4):573-84, https://doi. org/10.13075/ijomeh.1896.00570.

4. Jo W-K, Yu Ch-H. Public bus and taxicab drivers exposure to aromatic work-time volatile organic compounds. Environ Res. 2001;86(1):66-72, https://doi.org/10.1006/enrs. 2001.4257.

5. Sancini A, Fioravanti M, Ciarrocca M, Palermo P, Fiaschetti M, Schifano MP, et al. Pulmonary nodules in workers exposed to urban stressor. Environ Res. 2010;110(5):519-25, https://doi.org/10.1016/j.envres.2010.04.001.

6. DeMarini DM. Genotoxicity biomarkers associated with exposure to traffic and near-road atmospheres: A review. Mutagenesis 2013;28(5):485-505, https://doi.org/10.1093/mutage/ get042.

7. Brzeźnicki S, Gromiec J. [Exposure to selected aldehyde among municipal transport bus drivers]. Med Pr. 2002;53(2): 115-7. Polish. 
8. Goethel G, Brucker N, Moro AM, Charao MF, Fracasso R, Barth A, et al. Evaluation of genotoxicity in workers exposed to benzene and atmospheric pollutants. Mutat Res Genet Toxicol Environ Mutagen. 2014;770:61-5, https://doi. org/10.1016/j.mrgentox.2014.05.008.

9. Manini P, De Palma G, Andreoli R, Poli D, Mozzoni P, Folesani G, et al. Environmental and biological monitoring of benzene exposure in a cohort of Italian taxi drivers. Toxicol Lett. 2006;167(2):1421-51, https://doi.org/10.1016/j.toxlet.2006.08.016.

10. Zagury E, Le Moullec Y, Momas I. Exposure of Paris taxi drivers to automobile air pollutants within their vehicles. Occup Environ Med. 2000;57(6):406-10.

11. Riediker M, Williams R, Devlin R, Griggs T, Bromberg P. Exposure to particulate matter, volatile organic compounds, and other air pollutants inside patrol cars. Environ Sci Technol. 2003;37(10):2084-93.

12. Barnes NM, Ng TW, Ma KK, Lai KM. In-cabin air quality during driving and engine idling in air-conditioned private vehicles in Hong Kong. Int J Environ Res Public Health. 2018;15(4):611, https://doi.org/10.3390/ijerph15 040611.

13. Barth A, Brucker N, Moro AM, Nascimento S, Goethel G, Souto C, et al. Association between inflammation processes, DNA damage and exposure to environmental pollutants. Environ Sci Pollut Res Int. 2017;24(1):352-62, https://doi. org/10.1007/s11356-016-7772-0.17

14. Kumar J, Lind PM, Salihovic S, van Bavel B, Lind L, Ingelsson E. Influence of persistent organic pollutants on oxidative stress in population-based samples. Chemosphere. 2014;114:303-9, https://doi.org/10.1016/j.chemosphere. 2014.05.013.

15. Jimenez-Garza O, Gou L, Byun H-M, Carrieri M, Bartolucci GB, Barron-Vivanco BS, et al. Aberrant promoter methylation in genes related to hematopoietic malignancy in worker exposed to a VOC mixture. Toxicol Appl Pharmacol. 2018;339:65-72, https://doi.org/10.1016/j.taap.2017. 12.002 .
16. Mitchell J, editor. Some non-hetero polycyclic aromatic hydrocarbons and some related exposures. IARC monograph vol. 92. [Internet]. Lyon: International Agency for Research in Cancer; 2010 [cited 2018 Sep 22]. Available from: https:// monographs.iarc.fr/iarc-monographs-on-the-evaluation-ofcarcinogenic-risks-to-humans-29/.

17. Directive 98/70/EC of the European Parliament and of the Council of 13 October 1998 relating to the quality of petrol and diesel fuels and amending Council Directive 93/12/EEC. Off J Eur Union L 350/58 (Oct 13, 1998).

18. Maffei F, Hrelia P, Angelini S, Carbone F, Forti GC, Barbieri A, et al. Effects of environmental benzene: Micronucleus frequencies and hematological values in traffic police working in an urban area. Mutat Res. 2005;583(1):1-11, https://doi.org/10.1016/j.mrgentox.2005.01.011.

19. Talbott EO, Xu X, Youk AO, Rager JR, Stragand JA, Malek AM. Risk of leukemia as a result of community exposure to gasoline vapors: A follow-up study. Environ Res. 2011;111(4):597-602, https://doi.org/10.1016/j.envres. 2011.03.009.

20. Ciarrocca M, Tomei F, Caciari T, Capozzella A, Scimitto L, Nardone N, et al. Environmental and biological monitoring of benzene in traffic policemen, police drivers and rural outdoor male workers. J Environ Monit. 2012;14(6):1542-50, https://doi.org/10.1039/c2em30120b.

21. Rossner P Jr, Svecova V, Milcova A, Lnenickova Z, Solansky I, Sram RJ. Seasonal variability of oxidative stress markers in city bus drivers. Part I. Oxidative damage to DNA. Mutat Res. 2008;642(1-2):14-20, https://doi.org/10.1016/j.mrfmmm. 2008.03.003.

22. Li S, Chen S, Zhu L, Chen X, Yao C, Shen X. Concentrations and risk assessment of selected monoaromatic hydrocarbons in buses and bus stations of Hangzhou, China. Sci Total Environ. 2009;407(6):2004-11, https://doi.org/10.1016/j.scitotenv. 2008.11.020.

23. Melikian AA, Qu Q, Shore R, Li G, Li H, Jin X, et al. Personal exposure to different levels of benzene and its relationships to the urinary metabolites S-phenylmercapturic 
acid and trans,trans-muconic acid. J Chromatogr B Analyt Technol Biomed Life Sci. 2002;778(1-2):211-21, https://doi. org/10.1016/S0378-4347(01)00454-6.

24. Negri S, Bono R, Maestri L, Ghittori S, Imbriani M. High pressure liquid chromatographic-mass spectrometric determination of sorbic acid in urine: Verification of formation of trans,trans-muconic acid. Chem Biol Interact. 2005;153-154: 243-6, https://doi.org/10.1016/j.cbi.2005.03.029.

25. Kim K-H, Jahan SA, Kabir E, Brown RJC. A review of airborne polycyclic aromatic hydrocarbons (PAHs) and their human health effects. Environ Int. 2013;60:71-80, https:// doi.org/10.1016/j.envint.2013.07.019.

26. Galichet L. editor. A review of human carcinogens: chemical agents and related occupations. IARC monograph vol. 100F [Internet]. Lyon: International Agency for Research in Cancer; 2012 [cited 2018 Sep 25]. Available from: https:// monographs.iarc.fr/iarc-monographs-on-the-evaluation-ofcarcinogenic-risks-to-humans-16/.

27. Mitchell J, Muller K, editors. Diesel and gasoline engine exhaust and nitroarenes. IARC monograph vol. 105 [Internet]. Lyon: International Agency for Research in Cancer; 2014 [cited 2018 Sep 22]. Available from: https://monographs.iarc.fr/iarc-monographs-on-the-evaluation-of-carcinogenic-risks-to-humans-11/.

28. Rossner P Jr, Svecova V, Milcova A, Lnenickova Z, Solansky I, Santella RM, et al. Oxidative and nitrosative stress markers in bus drivers. Mutat Res. 2007;617(1-2):23-32, https://doi.org/10.1016/j.mrfmmm.2006.11.033.

29. Hansen AM, Wallin H, Binderup ML, Dybdahl M, Autrup H, Loft S, et al. Urinary 1-hydroxypyrene and mutagenicity in bus drivers and mail carriers exposed to urban air pollution in Denmark. Mutat Res. 2004;557(1):7-17, https:// doi.org/10.1016/j.mrgentox.2003.09.007.

30. Miller-Schulze JP, Paulsen M, Kameda T, Toriba A, Hayakawa K, Cassidy B, et al. Nitro-PAH exposures of occupationally-exposed traffic workers and associated urinary 1-nitropyrene metabolite concentrations. J Environ Sci. 2016;49: 213-21, https://doi.org/10.1016/j.jes.2016.06.007.
31. Brucker N, Moro AM, Charao MF, Durgante J, Freitas F, Baierle M, et al. Biomarkers of occupational exposure to air pollution, inflammation and oxidative damage in taxi drivers. Sci Total Environ. 2013;463-464:884-93, https://doi. org/10.1016/j.scitotenv.2013.06.098.

32. Świetlik R, Trojanowska M. [The structure of heavy metals emission from road traffic]. TTS. 2015;12:1519-21. Polish.

33. Krajowy Ośrodek Bilansowania i Zarządzania Emisjami (KOBiZE), Instytut Ochrony Środowiska - Państwowy Instytut Badawczy. [Report of the Institute of Environmental Protection - National Research Institute: National balance of emission of SO2, NOx, CO, NH3, NMLZO, dusts, heavy metals and persistent organic pollutants in the classification system of SNAP and NFR. A basic report]. Warszawa: Institute of Environmental Protection; 2015. Polish.

34. An HC, Sung JH, Lee J, Sim CS, Kim SH, Kim Y. The association between cadmium and lead exposure and blood pressure among workers of a smelting industry: A cross-sectional study. Ann Occup Environ Med. 2017;29:47, https:// doi.org/10.1186/s40557-017-0202-z.

35. Jakubowski M. [Lead and its inorganic compounds, except for arsenate (V), lead (II) and lead chromate (II) - calculated as lead, an inhalable fraction. Documentation of the proposed occupational exposure limit values]. Podst Met Oceny Środ Pr. 2014;2(80):111-44. Polish.

36. Shaffer RM, Gilbert SG. Reducing occupational lead exposures: Strengthened standards for a healthy workforce. Neurotoxicology. 2018;69:181-6, https://doi.org/10.1016/j.neuro. 2017.10.009.

37. Shraideh Z, Badran D, Hunaiti A, Battah A. Association between occupational lead exposure and plasma levels of selected oxidative stress related parameters in Jordanian automobile workers. Int J Occup Med Environ Health. 2018;31(4):517-25, https://doi.org/10.13075/ijomeh. 1896.01243.

38. Risom L, Moller P, Loft S. Oxidative stress-induced DNA damage by particulate air pollution. Mutat Res 2005;592(12):119-37, https://doi.org/10.1016/j.mrfmmm.2005.06.012. 
39. Hoxha M, Dioni L, Bonzini M, Pesatori AC, Fustinoni S, Cavallo $\mathrm{D}$, et al. Association between leukocyte telomere shortening and exposure to traffic pollution: A cross-sectional study on traffic officers and indoor office workers. Environ Health. 2009;8:41, https://doi.org/10.1186/1476-069X-8-41.

40. Bind MA, Baccareli A, Zanobetti A, Tarantini L, Suh H, Vokonas P, et al. Air pollution and markers of coagulation, inflammation, and endothelial function. Epidemiology. 2012;23(2):332-40, https://doi.org/10.1097/EDE.0b013e $31824523 f 0$.

41. Halliwell B. Free radicals and antioxidants: Updating a personal view. Nutr Rev. 2012;70(5):257-65, https://doi. org/10.1111/j.1753-4887.2012.00476.x.

42. Zeliger HI. Predicting disease onset in clinically healthy people. Interdiscip Toxicol. 2016;9(2):39-54, https://doi.org/ 10.1515/intox-2016-0006.

43. Birben E, Sahiner UM, Sackesen C, Erzurum S, Kalayci O. Oxidative stress and antioxidant defense. World Allergy Organ J. 2012;5(1):9-19, https://doi.org/10.1097/WOX.0b013 e3182439613.

44. Di Meo S, Reed TT, Venditti P, Victor VM. Role of ROS and RNS sources in physiological and pathological conditions. Oxid Med Cell Longev. 2016;2016:1245049, https:// doi.org/10.1155/2016/1245049.

45. Rossner P Jr, Svecova V, Milcova A, Lnenickova Z, Solansky I, Sram RJ. Seasonal variability of oxidative stress markers in city bus drivers. Part II. Oxidative damage to lipids and proteins. Mutat Res. 2008;642(1-2):21-7, https://doi. org/10.1016/j.mrfmmm.2008.03.004.

46. Bartosz G. Reactive oxygen species: Destroyers or messengers? Biochem Pharmacol. 2009;77(8):1303-15, https://doi. org/10.1016/j.bcp.2008.11.009.

47. Wang Y, Andrukhov O, Rausch-Fan X. Oxidative stress and antioxidant system in periodontitis. Front Physiol. 2017;8:910, https://doi.org/10.3389/fphys.2017.00910.

48. Lai C-H, Huang H-B, Chang Y-C, Su T-Y, Wang Y-C, Wang G-C, et al. Exposure to fine particulate matter causes oxidative and methylated damage in young adults.
A longitudinal study. Sci Total Environ. 2017;598:289-96, https://doi.org/10.1016/j.scitotenv.2017.04.079.

49. Loft S, Svoboda P, Kasai H, Tjonneland A, Moller P, Sorensen $\mathrm{M}$, et al. Prospective study of urinary excretion of 7-methylguanine and the risk of lung cancer: Effect of modification by mu class glutathione S-transferases. Int J Cancer. 2007;121(7):1579-84, https://doi.org/10.1002/ijc. 22863.

50. Sorensen M, Autrup H, Moller P, Hertel O, Jensen SS, Vinzents $P$, et al. Linking exposure to environmental pollutants with biological effects. Mutat Res. 2003;544(2-3):25571, https://doi.org/10.1016/j.mrrev.2003.06.010.

51. Lasheras C, Huerta JM, Gonzales S, Brana AF, Patterson AM, Fernandez S. Independent and interactive association of blood antioxidants and oxidative damager in elderly people. Free Radic Res. 2002;36(8):875-82, https://doi.org/ 10.1080/1071576021000005311.

52. Bagryantseva Y, Novotna B, Rossner P Jr, Chvatalova I, Milcova A, Svecova V, et al. Oxidative damage to biological macromolecules in Prague bus drivers and garagemen: Impact of air pollution and genetic polymorphisms. Toxicol Lett. 2010;199(1):60-8, https://doi.org/10.1016/j.toxlet. 2010.08.007.

53. Delfino RJ, Staimer N, Tjoa T, Gillen DL, Polidori A, Arha$\mathrm{mi} \mathrm{M}$, et al. Air pollution exposures and circulating biomarkers of effect in susceptible population: Clues to potential causal component mixtures and mechanisms. Environ Health Perspect. 2009;117(8):1232-8, https://doi.org/10.1289/ ehp.0800194.

54. Han Y-Y, Donovan M, Sung F-Ch. Increased urinary 8-hydroksy-2'-deoxyguanosine in long-distance bus drivers in Taiwan. Chemosphere. 2010;79(9):942-8, https://doi.org/10. 1016/j.chemosphere.2010.02.057.

55. Chuang CY, Lee CC, Chang YK, Sung FC. Oxidative DNA damage estimated by urinary 8-hydroxydeoxyguanosine: Influence of taxi driving, smoking and areca chewing. Chemosphere. 2003;52(7):1163-71, https://doi.org/10.1016/S00456535(03)00307-2. 
56. Chao MR, Hsu YW, Liu HH, Lin JH, Hu CW. Simultaneous detection of 3-nitrotyrosine and 3-nitro-4-hydroxyphenylacetic acid in human urine by online SPE LC-MS/MS and their association with oxidative and methylated DNA lesions. Chem Res Toxicol. 2015;28(5):995-1006, https://doi. org/10.1021/acs.chemrestox.5b00031.

57. Houben JM, Moonen HJ, van Schooten FJ, Hageman GJ. Telomere length assessment: Biomarker of chronic oxidative stress. Free Radic Biol Med. 2008;44(3):235-46, https://doi. org/10.1016/j.freeradbiomed.2007.10.001.

58. Hou L, Wang S, Dou Ch, Zhang X, Yu Y, Zheng Y, et al. Air pollution exposure and telomere length in highly exposed subjects in Beijing, China: A repeated-measure study. Environ Int. 2012;48:71-7, https://doi.org/10.1016/j. envint.2012.06.020.

59. Dioni L, Hoxha M, Nordio F, Bonzini M, Tarantini L, Alberti B, et al. Effects of short-term exposure to inhalable particulate matter on telomere length, telomerase expression and telomerase methylation in steel workers. Environ
Health Perspect. 2011;119(5):622-7, https://doi.org/10.1289/ ehp.1002486.

60. Minamino T, Miyauchi H, Yoshida T, Ishida Y, Yoshida H, Komuro I. Endothelial cell senescence in human atherosclerosis: Role of telomere in endothelial dysfunction. Circulation. 2002;105(13):1541-4, https://doi.org/10.1161/01.CIR. 0000013836.85741.17.

61. Bailey SM, Murnane JP. Telomeres, chromosome instability and cancer. Nucleic Acids Res. 2006;34(8):2408-17, https:// doi.org/10.1093/nar/gkl303.

62. Fitzpatrick AL, Kronmal RA, Gardner JP, Psaty BM, Jenny NS, Tracy RP, et al. Leukocyte telomere length and cardiovascular disease in cardiovascular health study. Am J Epidemiol. 2007;165(1):14-21, https://doi.org/10.1093/aje/ kwj346.

63. Wu X, Amos CI, Zhu Y, Grossman BH, Shay JW, Luo S, et al. Telomere dysfunction: A potential cancer predisposition factor. J Natl Cancer Inst. 2003;95(16):1211-8, https:// doi.org/10.1093/jnci/djg011.

This work is available in Open Access model and licensed under a Creative Commons Attribution-NonCommercial 3.0 Poland License - http://creativecommons.org/ licenses/by-nc/3.0/pl/deed.en. 